\title{
The Effects of $\gamma$ - Rays on The Optical Constants of ZnS Thin Films
}

\author{
Mustafa Shakir Hashim* Sami Salman Chiad *
}

\section{Nadir Fadhil Habubi*}

Received 26, January, 2009

Acceptance 8, April, 2009

\begin{abstract}
$\mathrm{ZnS}$ thin films were grown onto glass substrates by flash evaporation technique, the effects of $\gamma$ - rays on the optical constants of $\mathrm{ZnS}$ these films were studied. It was found that $\gamma$ - rays affected all the parameters under investigation.
\end{abstract}

Key words: thin film, flash evaporation, $\mathrm{ZnS}$, optical properties.

\section{Introduction:}

Zinc sulphide are widely used in many optical and electronic areas owing to its wide band gap $(3.7 \mathrm{eV})$, high refractive index, and high dielectric constant[1-2], low optical absorption in the visible and infrared spectral region ${ }^{[3]}$.

It can thus be used for the fabrication of optoelectronics devices such as blue light emitting diodes, electroluminescent devices, electrooptic modulator, optical coating, nwindow layer for thin film heterojunction solar cells, photodetector and especially photovoltaic devices [4-9], recently $\mathrm{ZnS}$ we used as in the treatment of wastewaters [10]. Various techniques have been employed to prepare $\mathrm{ZnS}$ thin films, such as successive ionic layer adsorption and reaction (SILAR) [11], glancing angle deposition [12], solution growth technique (SGT) [13], rf-magnetron sputtering [14], chemical bath deposition [15], pulsed laser deposition[16], atomic layer deposition[17] and chemical spray pyrolysis [18].

This research an attempt to fabricate $\mathrm{ZnS}$ using flash evaporation technique and study the optical constant of the as prepared thin films before and after exposure to $\gamma$-radiation.

\section{Materials and method:}

Polycrystalline $\mathrm{ZnS}$ thin films were grown on preheated glass substrates up to $100{ }^{\circ} \mathrm{C}$ by flash evaporation technique. High purity of $\mathrm{ZnS}$ (Aldrich company 99.99\%) were was evaporated by a molybdenum boat filament in a high vacuum chamber (pressure about $10^{-6}$ torr).

During the deposition of $\mathrm{ZnS}$ films, the boat and substrate were kept about $10 \mathrm{~cm}$ apart, this long distance results in the formation of quite uniform films, prior to deposition, the glass substrate were cleaned aqua - regia and washed in distilled water and isopropyl alcohol. The deposition rate was 0.8 $\mathrm{nm} / \mathrm{s}$ to obtain films with thickness of a bout $0.5 \pm 0.05 \mu \mathrm{m}$. Optical and transition spectra were recorded by double beam UV/VIS (Shimadzu Corporation Japan). in the wavelength range (300-900) nm. A ${ }^{60} \mathrm{CO}$ gamma - rays used to irradiate the thin films under investigation. A computer program was used to obtain the results concerning extinction coefficient, refractive index, real and imaginary

*Physics Department, Education College, Al-Mustansirya University, Baghdad. 
part of dielectric constant before and after irradiation.. XRD analysis was made using Philips $\mathrm{X}$-ray diffractometer with filtered $\mathrm{Cu} \quad \mathrm{K}_{\alpha}$ radiation source.

\section{Results and Discussion:}

The XRD spectrum of both unirradiated and irradiated $\mathrm{ZnS}$ in figure (1) suggesting Cubic phase (JCPDS card, No. 5-0566). It is seen that the peaks are more broadened and shifted to higher diffraction angle when the film is exposure to gamma particles. The optical properties of the film were determined from the transmission and reflection measurements in the rang (300-900) $\mathrm{nm}$.

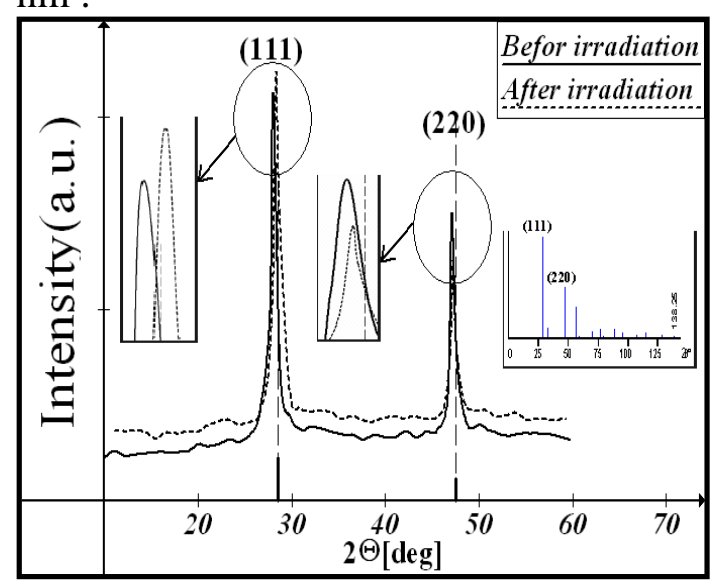

Fig. (1) XRD pattern of irradiated and unirradiated $\mathrm{ZnS}$ films.

For a better understanding of the effect of $\gamma$-irradiation on the optical properties of the investigated film, it is necessary to determine some optical

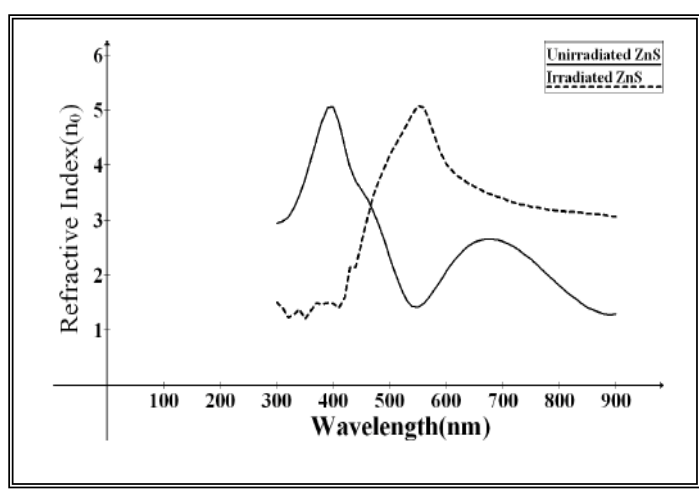

Fig.(2) Refractive Index vs. wavelength. constants such as the refractive index (n) and the extinction coefficient (k).Any absorbing medium can be characterized by the complex refractive index (n-_ik) and complex dielectric constant $\left(\varepsilon_{1}-i \varepsilon_{2}\right)$. The values of refractive index and extinction coefficient have calculated using the following relations [19]:

$$
\begin{aligned}
& R=\frac{(n-1)^{2}+k^{2}}{(n+1)^{2}+k^{2}} \\
& \mathrm{k}=\frac{\alpha \lambda}{4 \pi}
\end{aligned}
$$

Where $\mathrm{R}$ is the reflectance and $\lambda$ is the wavelength of the incident light .

Figure (2) shows the variation of refractive index with wavelength. the wavelengths ranging from $(380-530$ $\mathrm{nm}$ ), the value of refractive index decrease as the wavelength increase while the values of irradiated $\mathrm{ZnS}$ films within the same range increased, this variation may be attributed to various factors, such as the crystallinity of the film, density, electronic structure and the defects thus, the high value of the refractive index is an indication of high density of the film. Figure (3) shows the extinction coefficient $\left(\mathrm{k}_{0}\right)$ as a function of wavelength. $\mathrm{k}_{0}$ increases for irradiated sample because of increasing structural defect with gamma radiation and high value of extinction coefficient suggests low quality transparent films.

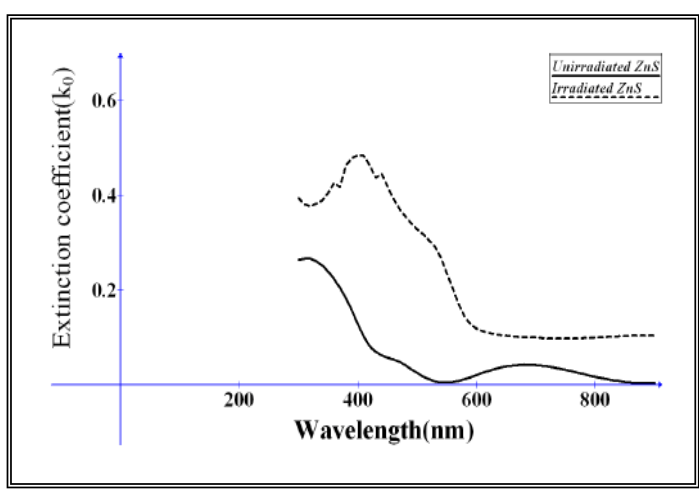

Fig. (3) Extinction coefficient vs. wavelength. 
The dielectric constants consists of real part $\left(\varepsilon_{1}\right) \&$ imaginary part $\left(\varepsilon_{2}\right)$, the variations of them with photon energy were determined and shown in figure

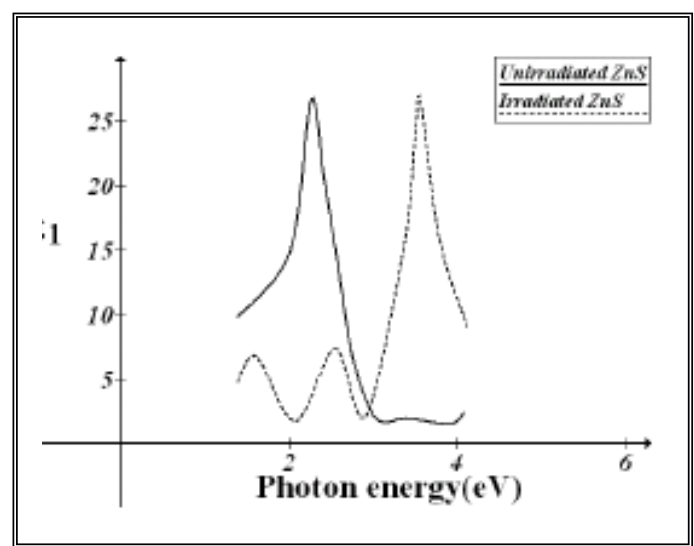

Fig. (4) $\varepsilon_{1}$ vs. Photon energy.

We can observe that the variation of $\boldsymbol{\varepsilon}_{\mathbf{1}}$ has similar trend to the variation of refractive index because of smaller values of $\left(\mathrm{k}_{0}\right)^{2}$ in comparison with $\left(\mathrm{n}_{0}\right)^{2}$ where $\left(\boldsymbol{\varepsilon}_{\mathbf{1}=}\left(\mathrm{n}_{0}\right)^{2}-\left(\mathrm{k}_{0}\right)^{2}\right)$, while the variation of $\boldsymbol{\varepsilon}_{\mathbf{2}}$ mainly depends on the variation of $\mathrm{k}_{0}$ values which are related to the variation of $\alpha$.

\section{Conclusions:}

The actions of irradiation by gamma ray on $\mathrm{ZnS}$ thin film are:

* The peaks of XRD are more broadened and shifted to higher diffraction angle when the film is exposure to gamma particles ,

* Increasing the absorption coefficient and extinction coefficient,

* $\boldsymbol{\varepsilon}_{\mathbf{1}}$ has similar trend to the variation of refractive index and

- $\boldsymbol{\varepsilon}_{2}$ values are related to the variation of $\alpha$.

\section{References :}

1.Singh, B. P., Singh, V., Tyagi, R.C. and Sharma, T.P. 2008. Effect of ambient hydrogen sulfide on the physical properties of vacuum evaporated thin films of zinc sulfide, Applied Surface Science. 254 : 22332237.
(4)\&(5), the variation of $\left(\varepsilon_{1}\right)$ could be attributed to the same reason of the variation of refractive index.

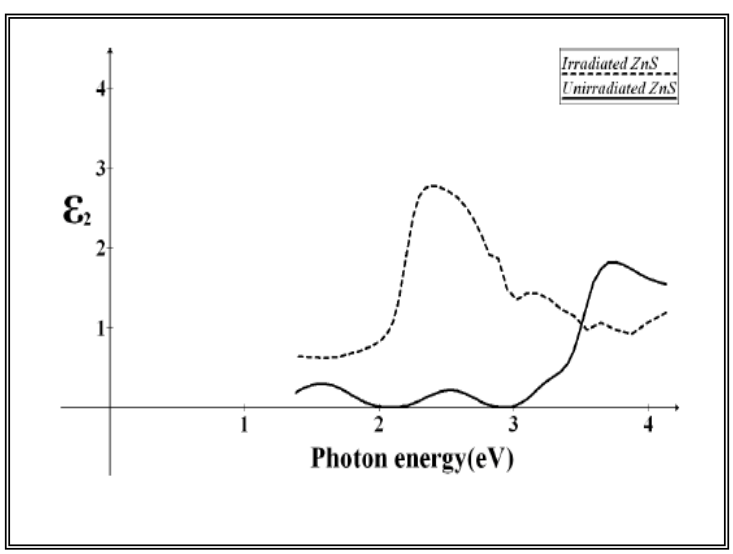

Fig. (5) $\varepsilon_{2}$ vs. Photon energy.

2.Hernandez-Fenollosa, M.A. , Lopez, M. C., Donderis, V., Gonzalez, M., Mari, B. and Ramos - Barrado, J. R. 2008. Role of precursors on morphology and optical properties of $\mathrm{ZnS}$ thin films prepared by chemical spray pyrolysis, Thin Solid Films, $516: 1622-1625$.

3.Wu, X., Lai, F., Lin, L., Lv, J. , Zhuang, B., Yan, Q. and Huang, Z .2008. Optical inhomogeneity of $\mathrm{ZnS}$ films deposited by thermal evaporation ,Applied Surface Science, $254:$ 6455-6460.

4. Yamaga, S., Yoshokawa, A. and Kasin, H.1990. Electrical and optical properties of donor doped $\mathrm{ZnS}$ films grown by low-pressure MOCVD, Journal of Crystal Growth.86 : 252256.

5.Nakamura, S., Y., Yamada , T., and Taguchi, J. 2000. Room-temperature $340 \mathrm{~nm}$ ultraviolet electroluminescence from $\mathrm{ZnS}$-based light-emitting diodes, Journal of Crystal Growth.214-205 (5) : 10911095.

6.Ndukwe, I. C.1996. Solution growth, characterization and applications of zinc sulphide thin films, Solar Energy Materials and Solar Cells., 40 : 123-131. 
7.Kundu, S. and Olsen, L. C. 2005. chemical bath deposition zinc sulfide buffer layers for copper indium gallium sulfar-selenide solar cell and device analysis, Thin solid films 471: 298-303

8.Yazici, A. N., Oztas, M.,. Kafadar, V.E., Bedir,M.and Toktamis, H.2007. The analysis of thermoluminescent glow peaks of copper doped $\mathrm{ZnS}$ thin films after $\beta$ irradiation . Journal of Luminescence, 124 : 58-66.

9.Vidal, J., Vigil, O., Melo, O.D., Lopez, N., G. and Zelaya-Angel, O.2002. Influence of $\mathrm{NH}_{3}$ concentration and annealing in the properties of chemical bath deposited ZnS films, Materials Chemistry and Physics, 61: 139-142.

10. Pouretedal, H. R., Norozi, A., Keshavarz, M. H., and Semnani, A.2009. Nanoparticles of zinc sulfide doped with manganese, nickel and copper as nanophotocatalyst in the degradation of organic dyes, Journal of Hazardous Materials, 162 : 674681.

11. Ates, A., M. Yildirim, A., Kundakci, M. and Astam, A.2007. Annealing and light effect on optical and electrical properties of $\mathrm{ZnS}$ thin films grown with the SILAR method, Materials Science in Semiconductor Processing, $10: 281-286$.

12. Wang, S., Fu, X., Xia, G., Wang, J., Shao, J. and Fan, Z.2006. Structure and optical properties of $\mathrm{ZnS}$ thin films grown by glancing angle deposition, Applied Surface Science $252: 87348737$.

13. Chavhan, S. and Sharma, R. P.2005. Growth, structural and optical transport properties of nanocrystal $\mathrm{Zn}_{1-\mathrm{x}} \mathrm{CdS}$ thin films deposited by solution growth technique (SGT) for photosensor applications, Journal of Physics and Chemistry of Solids , 66 : 1721-1726.

14. Ghosh, P. K., Jana, S., Nandy, S. and Chattopadhyay, K. K.2007. Sizedependent optical and dielectric properties of nanocrystalline $\mathrm{ZnS}$ thin films synthesized via rf-magnetron sputtering technique, Materials Research Bulletin, 42 : 505-514.

15. Ladar, M., Popovici, E., Baldea, I., Greeu, R. and Indrea, E.2007. Studies on chemical bath deposited zinc sulphide thin films with special optical properties , Journal of Alloys and Compounds, 434 - 435 : 697-700.

16. Yano, S., Schroeder, R., Vllich, B. and Sakai, H.2003. Absorption and photocurrent properties of thin $\mathrm{ZnS}$ films formed by pulsed-laser deposition on quartz, Thin Solid Films, 423 : 273-276.

17. kim,Y. S., S. and Yuh, J.2004. Studies on polycrystalline $\mathrm{ZnS}$ thin films grown by atomic layer deposition for electroluminescent applications, Applied Surface Science, 229 : 105-111.

18. Elidrissi, B., M., Addou, Regrui, M., Bougrine, Kachouane, A. and Bernede, j. c.2001. Structure, composition and optical properties of $\mathrm{ZnS}$ thin films prepared by spray pyrolysis, Materials Chemistry and Physics, 68 : 175-179.

19. Abay, B., Gu" der, H.S. and Yogurtcu,Y.K.1999. UrbachMartienssen's tails in layered semiconductor GaSe ,Solid State Communications , 112 : 489-494.

\section{تأثير أشعة كاما على الثوابت البصرية لأغثية كبريتيد الخارصين الرقيقة}


*نادر فاضل حبويب

سامي سلمان جياد

مصطفى شاكر هاشمث*

* الجامعة المستنصرية ـ- كلية التربية - قسم الفيزياء

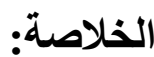

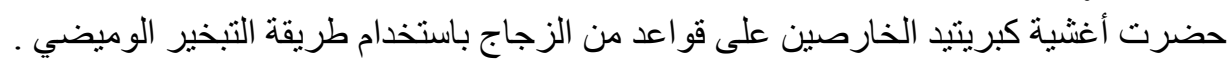

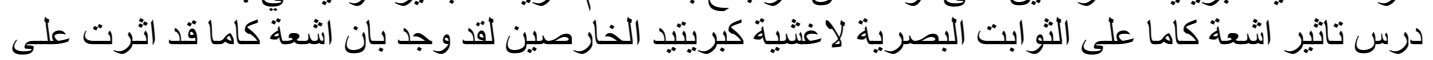
كافة العو امل قيد الدر اسة. 